\title{
Crescentic Glomerulonephritis During the Course of Squamous Cell Lung Cancer: an Uncommon Paraneoplastic Manifestation?
}

\author{
Salih INAL ${ }^{1}$, Sibel GOKCAY ${ }^{1}$, Kürşad ONEC ${ }^{1}$, I. Isık GONUL ${ }^{2}$,Yasemin ERTEN ${ }^{1}$ \\ ${ }^{1}$ Gazi University Faculty of Medicine, Department of Nephrology \\ ${ }^{2}$ Gazi University Faculty of Medicine, Department of Pathology, Ankara, TURKEY
}

To the editor,

A 57-year-old man was admitted to our nephrology department with complaints of pitting edema, anorexia, fatigue, and oliguria. Two years ago he had been diagnosed as squamous cell cancer of the lung and had been treated with 8 cycles of cisplatin and paclitaxel, followed by 5-day long radiation therapy. Afterwards he had stable disease and was regularly followed-up by oncology department. After completion of chemotherapy, his serum creatinine was within normal range and urinalysis was totally normal.

The patient did not describe vasculitic symptoms such as arthritis, skin lesions, neuropathy, and others. He noticed decreased urinary output and macroscopic hematuria for 10 days. In physical examination there was a mild pretibial edema and blood pressure was normal, being 130/85 $\mathrm{mmHg}$ on admission. Blood count findings were within normal limits. On admission, marked renal dysfunction was noted with blood urea nitrogen: $53 \mathrm{mg} / \mathrm{dL}$ and serum creatinine: $4.87 \mathrm{mg} / \mathrm{dL}$. Serum creatinine level increased gradually, up to $5.93 \mathrm{mg} / \mathrm{dL}$ and 3.4 gr per 24 hour proteinuria was also detected. Urinalysis testing revealed numerous dysmorphic red blood cells, granular and red blood cell casts. Ultrasonography showed two normal-sized kidneys and normal blood flow in renal arteries and veins. Autoantibodies, such as anti-glomerular basement membrane (GBM) antibody, perinuclear antineutrophil cytoplasmic autoantibodies (p-ANCA), cytoplasmic antineutrophil cytoplasmic autoantibodies (c-ANCA), antinuclear antibodies (ANA), and anti-double strand DNA (anti-ds DNA) were negative. Cryoglobulin, and markers of hepatitis B and $\mathrm{C}$ were negative. Complement levels and serum immunoglobulin levels were also within normal ranges.

During follow-up, urine output decreased gradually and renal functions worsened progressively. A kidney biopsy was performed. Histopathologic findings of biopsy showed diffuse necrotizing crescentic GN. In biopsy specimen, twenty-six glomeruli were present; 10 glomeruli were globally sclerosed, 6 glomeruli showed cellular crescents, 4 glomeruli showed fibrocellular crescents and well-defined chronic tubulo-interstistial scarring. Direct immunofluorescence studies did not show any linear staining for $\operatorname{IgG}, \operatorname{IgM}, \operatorname{Ig} \mathrm{A}$ and complements along the glomerular capillary walls. In differential diagnosis, ANCA associated vasculitis, acute tubular necrosis and acute interstitial nephritis were ruled out and a diagnosis of crescentic GN was rendered based on the above findings.

He was not treated with immunosuppressive therapy because he had a tumoral mass in chest $X$ ray and he was taken under an oncological evaluation presuming lung cancer activation.

Additionally, tumor treatment is essential for correcting paraneoplastic syndromes, therefore the primary treatment should be directed to the cancer in such cases..$^{1,2}$ 


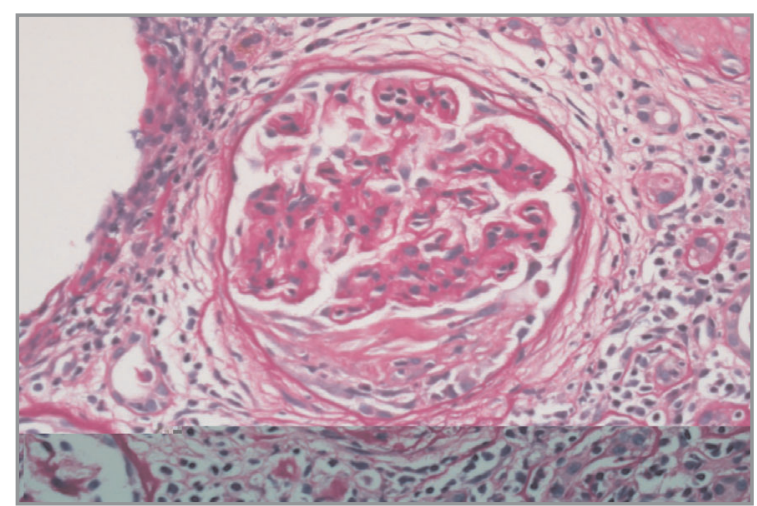

Figure 1. Glomerulus with a fibrocellular crescent formation (PAS stain X400)

On following days, the patient's renal functions deteriorated and could not be recovered. He is now on regular hemodialysis.

In this report, we presented an unusual presentation of crescentic GN occuring in a 57-year-old man in the setting of squamous cell cancer of lung that was treated with chemotherapy and radiotherapy. Rapidly progressive or crescentic is the term used to describe the clinical course of several forms of glomerulonephritis; their common characteristic is the presence of crescents. ${ }^{3}$ The stimulus for crescent formation is the accumulation of fibrin in Bowman space, as a result of necrosis or disruption of the glomerular capillary wall with or without immune deposits. There are reports of crescentic GN occurring in association with carcinomas. These include gastric carcinoma, renal cell carcinoma, metastatic adenocarcinoma of the lung, hepatocellular carcinoma, breast carcinoma and prostatic carcinoma..$^{4-9}$ Gastric and renal cell carcinomas are more commonly associated with crescentic GN and in many cases of crescentic GN reported with carcinomas, ANCA was also found to be positive.?

To our knowledge, there were only four reported cases of crescentic GN developed after the diagnosis of lung cancer. Of these cases, one had small cell cancer and 3 cases had squamous and bronchial carcinomas and all had ANCA positivity 1 . However, in our patient serological markers for GN including ANCA was negative. We may speculate that malignancy associated ANCA positive vasculitis might be the etiological factor for those crescentic GN cases. In the absence of another evident cause of the RPGN, the ANCA negative crescentic
GN seen in our patient might be considered as an uncommon paraneoplastic manifestation of squamous cell lung cancer. We conclude that patients with cancer and acute renal failure should be carefully evaluated with urinary sediment tests and crescentic GN should be kept in mind in differential diagnosis.

\section{REFERENCES}

1. Bacchetta J, Juillard L, Cochat P, Droz JP. Paraneoplastic glomerular diseases and malignancies. Crit Rev Oncol Hematol 70: 39-58, 2009.

2. Jefferson JA, Couser WG. Therapy of membranous nephropathy associated with malignancy and secondary causes. Semin Nephrol 23: 400-405, 2003.

3. Esnault VL, Moreau A, Testa A, Besnier D. Crescentic glomerulonephritis. Nephrol Ther 2: 446-460, 2006.

4. Chan TM, Cheng IK, Wong $\mathrm{KL}$, et al. Crescentic IgA glomerulonephritis following interleukin-2 therapy for hepatocellular carcinoma of the liver. Am J Nephrol 11: 493-496, 1991.

5. Yavuzsen T, Oztop I, Yilmaz U, et al. Gastric cancer diagnosed in a patient with crescentic glomerulonephritis. Gastric Cancer 6: 267-269, 2003.

6. Karim MY, Frankel A, Paradinas FJ, Moss J. Antineutrophil cytoplasmic antibody-positive crescentic nephritis occurring together with renal cell carcinoma. Nephron 85: 368-370, 2000.

7. Baschinsky DY, Baker PB, Niemann TH, Wilmer WA. Pauci-immune ANCA-positive crescentic glomerulonephritis associated with metastatic adenocarcinoma of the lung. Am J Kidney Dis 36: 24, 2000.

8. Haskell LP, Fusco M, Wadler S, et al. Crescentic glomerulo-nephritis associated with prostatic carcinoma: Evidence of immune-mediated glomerular injury. Am J Med 88: 189-192, 1990.

9. Sethi S, Sahani M, Oei LS, Rao R. Crescentic glomerulonephritis and dense deposit disease in a woman with breast carcinoma on immunosuppressive chemotherapy. Am J Kidney Dis 44: 33-37, 2004.

\section{Correspondence}

Dr. Salih INAL

Gazi Üniversitesi Tıp Fakültesi Hastanesi

Nefroloji Bilim Dalı

Beşevler, ANKARA / TURKEY

Tel: (+90.312) 2025229

Fax: (+90.312) 2129006

e-mail: salihinal@yahoo.com 